\title{
Faktor Prediktor Malnutrisi Rumah Sakit pada Anak
}

\author{
Elvia Maryani, Endy Paryanto Prawirohartono, Sasmito Nugroho \\ Bagian Ilmu Kesehatan Anak Fakultas Kedokteran Universitas Gadjah Mada/ RSUP Dr. Sardjito, Yogyakarta
}

\begin{abstract}
Latar belakang. Perawatan anak di rumah sakit berisiko terhadap kejadian malnutrisi rumah sakit akibat dari penurunan asupan makan, hipermetabolisme, malabsorbsi dan kehilangan nutrisi. Malnutrisi berdampak pada peningkatan kejadian komplikasi penyakit, lama rawat, dan biaya pelayanan.

Tujuan. Melakukan evaluasi asupan makan, status nutrisi awal, demam, diare, keganasan, diagnosis multipel dan derajat penyakit sebagai faktor prediktor malnutrisi rumah sakit pada anak.

Metode. Penelitian prospektif dilakukan pada pasien anak yang dirawat di RSUP Dr Sardjito usia 1 bulan sampai 18 tahun pada bulan September sampai dengan Oktober 2012. Subyek diambil secara konsekutif. Didapat 224 subyek, 20 tidak dianalisis karena data tidak lengkap. Berat badan diukur setiap hari pada kondisi yang sama sampai dengan pasien dipulangkan. Malnutrisi rumah sakit jika penurunan berat badan $\geq 2 \%$ (perawatan $\leq 7$ hari), $5 \%$ (perawatan 8 sampai 30 hari) atau 10\% (perawatan $\geq 30$ hari). Asupan makan, status nutrisi, demam, diare, keganasan, diagnosis multipel dan derajat penyakit dinilai dalam 48 jam pertama perawatan.

Hasil. Proporsi malnutrisi rumah sakit pada anak 27\%. Analisis multivariat menunjukkan bahwa derajat penyakit adalah faktor prediktor malnutrisi rumah sakit pada anak $(\mathrm{RR}=2,56$; $\mathrm{IK}=1,22-5,38)$.
\end{abstract}

Kesimpulan: Derajat penyakit adalah faktor prediktor malnutrisi rumah sakit pada anak. Sari Pediatri 2016;18(4):278-84

Kata kunci: malnutrisi rumah sakit, anak, derajat penyakit

\section{Predictors of In-Hospital Malnutrition in Children}

Elvia Maryani, Endy Paryanto Prawirohartono, Sasmito Nugroho

Background. Children admitted to the hospital are at risk to develop malnutrition due to decreased of food intake, hypermetabolism, malabsorbtion and loss of nutrients. In-hospital malnutrition is associated with increased risk of adverse clinical events, prolonged hospital stay and health cost.

Objective To evaluate of food intake, initial nutritional status, fever, diarrhea, malignancy, multiple diagnosis and severity of disease as predictors in-hospital malnutrition in children.

Methods. We conducted a prospective study on 1 month-18 year old children hospitalized at Sardjito Hospital Yogyakarta between September-October 2012. The subjects were collected using consecutive sampling methods. This study recruited 224 subjects. There were 20 subjects that were not analyzed due to incomplete data. Weight and height were measured as part of routine admission procedure. Weight was measured daily in the same condition until discharge. In-hospital malnutrition was defined as a weight loss of $\geq 2 \%$ (lenght of stay $\leq 7$ days), $5 \%$ (lenght of stay $8-30$ days) or $10 \%$ (lenght of stay $>30$ days). Food intake, nutritional status, fever, diarrhea, malignancy, multiple diagnosis and severity of disease were assessed within 48 hours.

Result. The proportion of in-hospital malnutrition in children was $27 \%$. In the multivariate statistical analysis, the only significant predictor of in-hospital malnutrition was the severity of disease ( $R R=2,56 ; \mathrm{IK}=1,22-5,38)$.

Conclusion. The severity of disease is a predictor of in-hospital malnutrition in children. Sari Pediatri 2016;18(4):278-84

Keyword: in-hospital malnutrition, children, severity of disease

Alamat korespondensi: Dr. Elvia Maryani. Bagian Ilmu Kesehatan Anak Fakultas Kedokteran Universitas Gadjah Mada/ RSUP Dr.Sardjito, Yogyakarta. Email: elviamaryani@yahoo.com 
M alnutrisi rumah sakit (MRS) adalah malnutrisi yang terjadi selama perawatan di rumah sakit yang ditandai dengan penurunan berat badan $\geq 2 \%$ dalam perawatan $\leq 7$ hari atau $5 \%$ dalam perawatan 8 sampai 30 hari atau $10 \%$ dalam perawatan $\geq 30$ hari. ${ }^{1}{ }^{12}$ Setiap anak yang dirawat di rumah sakit berisiko mengalami MRS, dan masih menjadi masalah dalam penanganan pasien. Prevalensi MRS pada anak cukup tinggi, antara 6,1\%-51,6\% tergantung dari populasi dan definisi operasional yang digunakan. ${ }^{3,4}$

Malnutrisi rumah sakit berdampak pada peningkatan angka morbiditas, mortalitas, komplikasi penyakit, dan lama rawat inap yang berpengaruh pada biaya pelayanan. ${ }^{5}$ Pasien dengan MRS memiliki risiko 1,6 kali mengalami komplikasi penyakit dibandingkan pasien tanpa malnutrisi. Angka mortalitas pada pasien dengan MRS meningkat 3 kali dibanding pasien tanpa malnutrisi. Lama rawat memanjang 1,5 hingga 2 kali dan biaya pelayanan dapat meningkat hingga 3 kali lipat. ${ }^{6}$ Penyebab MRS adalah penurunan asupan makan, hipermetabolisme, malabsorbsi, dan kehilangan nutrisi. Sekalipun angka kejadian MRS tinggi, masih banyak dokter anak dan tenaga kesehatan yang belum mampu mengenali kejadian MRS. ${ }^{7}$ Hampir $70 \%$ pasien yang mengalami MRS tidak terdiagnosis dan tidak mendapat penanganan yang memadai. ${ }^{8}$

\section{Metode}

Penelitian dengan rancangan kohort prospektif, dilibatkan 224 subyek penelitian. Terdapat 20 subyek yang loss to follow up. Subyek yang diikutsertakan adalah pasien baru usia $\geq 1$ bulan sampai dengan 18 tahun yang dirawat di ruang rawat inap kelas 2 dan 3 Instalasi Kesehatan Anak RSUP Dr. Sardjito, Yogyakarta, lama rawat minimal 48 jam, dapat dilakukan pengukuran berat/ tinggi badan dan tidak terdapat massa atau tumor yang jelas, edema yang jelas, asitas dan hidrosefalus yang akan memengaruhi pengukuran berat badan. Jika data medis tidak lengkap, subyek tidak diikutsertakan dalam penelitian. Kriteria drop out adalah pindah rawat ke unit lain sebelum diizinkan pulang, membutuhkan rawat intensif di PICU dan tidak kembali ke ruang rawat inap, meninggal atau pulang atas permintaan pasien/keluarga.

Subyek yang memenuhi kriteria inklusi dan tidak memenuhi kriteria eksklusi dinilai berat/tinggi badan dalam 24 jam pertama perawatan. Selama $2 \times 24$ jam pertama dilakukan penilaian asupan makan, status nutrisi pada saat datang, demam, diare, keganasan, diagnosis multipel dan derajat penyakit. Berat badan diukur dengan timbangan digital (baby scale) merk Seca dalam satuan gram untuk usia kurang dari 1 tahun, untuk usia lebih dari 1 tahun atau sudah dapat berjalan dengan timbangan digital injak merek Camry dengan ketepatan $0,5 \mathrm{~kg}$. Pengukuran dilakukan dalam busana minimal untuk usia $\geq 1$ tahun dan tanpa busana untuk usia $<1$ tahun. Untuk anak yang mengalami dehidrasi pengukuran dilakukan saat dehidrasi telah teratasi. Berat badan diukur setiap hari pada kondisi yang sama sampai dengan pasien dipulangkan.

Asupan makan dinilai berdasar angka kecukupan gizi (AKG) sesuai umur yang dikeluarkan oleh Kementrian Kesehatan RI, dibedakan $>80 \%$ AKG dan $<80 \%$ AKG dengan teknik food recall. Status nutrisi ditentukan oleh $\mathrm{BB} / \mathrm{TB}$ pada anak usia $\leq 5$ tahun dan IMT/U pada usia lebih dari 5 tahun sampai 18 tahun. Berisiko bila $Z$ score $<-2$ SD dan tidak berisiko bila $Z$ score $\geq-2 \mathrm{SD}$. Demam apabila didapatkan $\geq 2 \mathrm{kali}$ pengukuran suhu di atas $37,5^{\circ} \mathrm{C}$ selama 2 hari pertama perawatan. Diare apabila dalam 2 hari berturut-turut terdapat buang air besar $\geq 3$ kali dengan konsistensi cair. Penyakit keganasan dengan massa yang telah mengecil atau telah dilakukan tindakan bedah atau sudah menjalani kemoterapi. Diagnosis multipel apabila dijumpai dua diagnosis utama atau lebih dalam $2 \times 24$ jam pertama hari perawatan. Diagnosis penyakit yang satu bukan merupakan bagian dari diagnosis penyakit yang lain.

Derajat penyakit dibedakan menjadi, derajat 1 yaitu pasien yang dirawat inap dengan faktor stres ringan seperti dirawat untuk untuk menjalani prosedur diagnostik, infeksi minor yang tidak memerlukan rawat inap, episode penyakit tertentu dan operasi minor. Derajat 2 yaitu pasien yang dirawat dengan faktor stres sedang misalnya infeksi berat tapi tidak mengancam jiwa, pembedahan elektif, fraktur, penyakit kronis tanpa perburukan kondisi klinis, dan penyakit inflamasi saluran cerna. Derajat 3 yaitu pasien yang dirawat dengan faktor stres berat seperti AIDS, keganasan, sepsis berat, tindakan bedah mayor, multiple trauma, penyakit kronis yang disertai perburukan kondisi klinis dan depresi berat.

Uji statistik yang digunakan chi-square untuk variabel prediktor dengan outcome. Variabel yang 
mempunyai nilai $\mathrm{p}<0,25$ dimasukkan dalam analisis multivariat dengan regresi logistik. Penelitian ini telah mendapatkan persetujuan dari Komite Etik Penelitian Kesehatan (KEPK) Fakultas Kedokteran UGM dan RSUP Dr. Sardjito Yogyakarta.

\section{Hasil}

Terdapat 224 subyek penelitian yang memenuhi kriteria inklusi dan tidak memenuhi kriteria eksklusi. Terdapat 20 responden loss to follow up karena

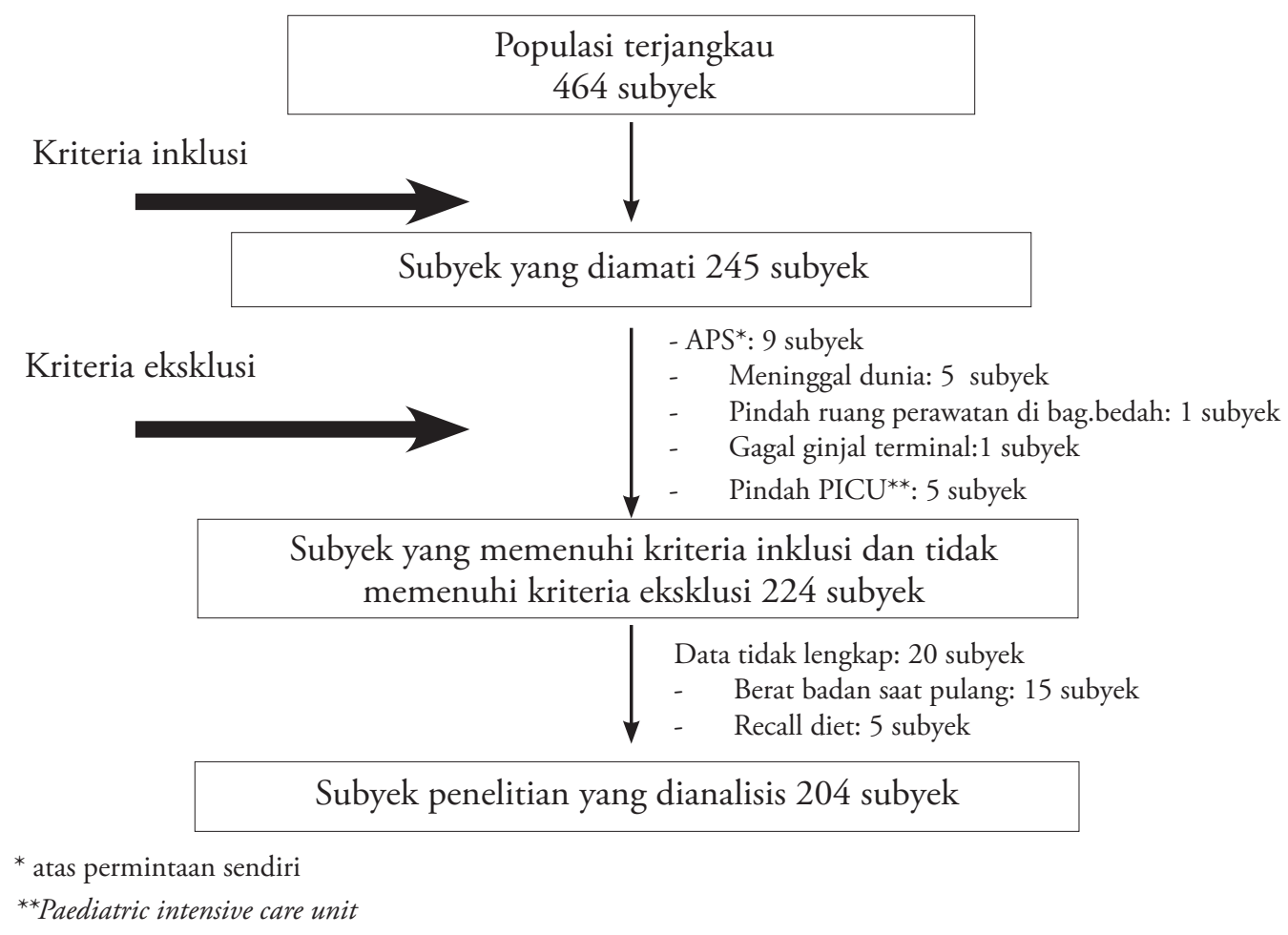

Gambar 1. Skema rekruitmen subjek penelitian

Tabel 1. Karakteristik dasar subyek penelitian

\begin{tabular}{|c|c|c|c|}
\hline \multirow[b]{2}{*}{ Karakteristik } & \multirow[b]{2}{*}{$\begin{array}{c}\text { Total } \\
(\mathrm{n}=204)\end{array}$} & \multicolumn{2}{|c|}{ Malnutrisi rumah sakit* } \\
\hline & & $\begin{array}{c}\mathrm{Ya} \\
(\mathrm{n}=55)\end{array}$ & $\begin{array}{c}\text { Tidak } \\
(\mathrm{n}=149)\end{array}$ \\
\hline \multicolumn{4}{|c|}{ Umur, bulan, n (\%) } \\
\hline $1-3$ & $7 \quad(3,4)$ & $2 \quad(3,6)$ & $5(3,4)$ \\
\hline $4-12$ & $14(6,9)$ & $3 \quad(5,5)$ & $11(7,4)$ \\
\hline $13-60$ & $56 \quad(27,5)$ & $16(29,1)$ & $40(26,8)$ \\
\hline$>60$ & $127(62,2)$ & $34(61,8)$ & $93(62,4)$ \\
\hline \multicolumn{4}{|c|}{ Jenis kelamin, $\mathrm{n}(\%)$} \\
\hline Laki-laki & $130(63,7)$ & $41(74,5)$ & $89(59,7)$ \\
\hline Perempuan & $74 \quad(36,3)$ & $14(25,5)$ & $60(40,3)$ \\
\hline \multicolumn{4}{|c|}{ Lama perawatan, hari n (\%) } \\
\hline$<7$ & $101(49,5)$ & $35(63,6)$ & $66(44,3)$ \\
\hline$\geq 7$ & $104(50,5)$ & $20(36,4)$ & $84(56,4)$ \\
\hline
\end{tabular}


data tidak lengkap sehingga didapat 204 subyek yang dapat dianalisis. Skema rekruitmen subyek penelitian tertera pada Gambar 1. Karakteristik dasar subyek penelitian tertera pada Tabel 1 .

Proporsi MRS 27\%. Semakin tua umur anak semakin tinggi kejadiannya, yaitu $61,8 \%$ pada umur $>60$ bulan dibandingkan dengan umur 1-3 bulan 3,6\%. Rasio laki-laki : perempuan adalah 3:1. Bagian terbesar anak dengan MRS lama perawatan lebih dari 7 hari $(63,6 \%)$.

Demam yang berlangsung dalam 2 hari pertama rawat, penyakit derajat 3, dan diagnosis multipel merupakan faktor prognostik MRS yang mempunyai nilai $\mathrm{p}<0,25$ sehingga diuji dalam analisis multivariat. Selanjutnya, analisis multivariat menunjukkan bahwa anak dengan derajat penyakit 3 mempunyai risiko 2,57 kali menderita malnutrisi rumah sakit dibandingkan dengan anak dengan derajat penyakit 1 dan 2 (RR 2,57; IK95\% 1,22-2,58).

\section{Pembahasan}

Proporsi MRS pada anak di RSUP Dr Sardjito (27\%), tidak jauh berbeda dengan insidensi di RS Sanglah Denpasar (30,1\%), RS Saiful Anwar Malang (24,3\%) serta RS Moehammad Hoesin Palembang (37\%). ${ }^{9-11}$ Prevalensi MRS pada anak masih tinggi antara 6,1\%$51,6 \%$ dan meningkat sesuai dengan lama perawatan. ${ }^{4}$ Derajat penyakit 3 berisiko menderita MRS 2,57 kali dibandingkan pasien derajat penyakit 1 dan 2 . Kejadian MRS meningkat seiring dengan peningkatan derajat penyakit yang ada. Hubungan bermakna antara derajat penyakit dengan kejadian MRS tidak diperantarai oleh rendahnya asupan makan.

Derajat penyakit merupakan penyebab sekunder dari MRS yang dapat memengaruhi asupan makan, peningkatan kebutuhan energi, perubahan metabolisme, dan malabsorbsi. Selain itu, MRS berat terkait dengan beratnya penyakit dan komplikasi yang

Tabel 2. Analisis univariat dan multivariat faktor prognostik MRS

\begin{tabular}{|c|c|c|c|c|c|c|}
\hline \multirow[t]{2}{*}{ Variabel } & \multirow{2}{*}{$\begin{array}{c}\mathrm{N} \\
\text { Total }\end{array}$} & \multicolumn{3}{|c|}{ Univariat } & \multicolumn{2}{|c|}{ Multivariat } \\
\hline & & $\mathrm{RR}$ & IK95\% & $\mathrm{p}$ & RR & IK95\% \\
\hline \multicolumn{7}{|l|}{ Asupan makan $\left(\mathrm{AKG}^{*}\right)$} \\
\hline$\geq 80 \%$ & 39 & 1 & & & & \\
\hline$<80 \%$ & 165 & 1,04 & $0,51-2,11$ & 0,92 & - & - \\
\hline \multicolumn{7}{|l|}{ Status nutrisi } \\
\hline $\mathrm{WHZ}_{\text {atau }} \mathrm{BAZ}^{* *}>-2 \mathrm{SD}^{* * *}$ & 146 & 1 & & & & \\
\hline $\mathrm{WHZ}_{\text {atau }} \mathrm{BAZ}^{* *} \leq-2 \mathrm{SD}^{* * *}$ & 58 & 0,82 & $0,40-1,64$ & 0,57 & - & - \\
\hline \multicolumn{7}{|l|}{ Demam } \\
\hline Tidak & 158 & 1 & & & & \\
\hline Ya & 46 & 2,70 & $1,35-5,41$ & 0,004 & 1,87 & $0,89-3,94$ \\
\hline \multicolumn{7}{|l|}{ Diare } \\
\hline Tidak & 194 & 1 & & & & \\
\hline $\mathrm{Ya}$ & 10 & 1,17 & $0,29-4,70$ & 0,82 & - & - \\
\hline \multicolumn{7}{|l|}{ Keganasan } \\
\hline Tidak & 98 & 1 & & & & \\
\hline Ya & 106 & 1,27 & $0,68-2,37$ & 0,44 & - & - \\
\hline \multicolumn{7}{|l|}{ Diagnosis multipel } \\
\hline Tunggal & 141 & 1 & & & & \\
\hline Multipel & 63 & 2,35 & $1,23-4,48$ & 0,008 & 1,41 & $0,68-2,95$ \\
\hline \multicolumn{7}{|l|}{ Derajat penyakit } \\
\hline 1 atau 2 & 137 & 1 & & & & \\
\hline 3 & 67 & 3,51 & $1,84-6,69$ & 0,000 & 2,57 & $1,22-5,38$ \\
\hline
\end{tabular}


terjadi. ${ }^{12,13}$ Derajat penyakit 3 didefinisikan sebagai penyakit kronis yang mengalami perburukan atau penyakit berat yang berada pada episode akut. ${ }^{14}$ Kedua keadaan tersebut meningkatkan risiko komplikasi penyakit dan kematian. ${ }^{13}$ Perburukan yang terjadi tidak hanya terlihat secara antropometri (penurunan berat badan), tetapi juga berdasarkan pemeriksaan biokimia dan imunologi, seperti pemeriksaan kadar albumin dan imunoglobulin yang cenderung turun seiring dengan perburukan penyakit. Respon metabolik pada kondisi critically ill di antaranya terjadi peningkatan kadar CRP, $\alpha 1$ - antitripsin dan fibronetin. Sebaliknya, beberapa protein seperti imunoglobulin $G$ dan $M$, komplemen, prealbumin, transferin, ceruloplasmin dan albumin kadarnya menurun. ${ }^{15}$ Dalam kondisi critically ill dilepaskan marker inflamasi seperti CRP dan IL-6 yang memengaruhi status nutrisi pasien selama perawatan yang menyebabkan MRS. ${ }^{7}$ Kadar prealbumin (transthyretin) dalam serum dapat digunakan sebagai alat deteksi MRS. Kadar prealbumin dapat menggambarkan outcome pasien selama perawatan sehingga dapat digunakan sebagai marker untuk evaluasi nutrisi terutama akibat penyakit sehingga terjadi malnutrisi. ${ }^{16-18}$

Kami tidak meneliti kadar albumin, imunoglobulin, CRP, IL-6 dan pre-albumin sehingga kontribusinya sebagai variabel antara derajat penyakit dengan kejadian MRS tidak dapat dinilai. Sekalipun demikian, dalam analisis variabel antara derajat penyakit, terdapat hubungan dengan komplikasi penyakit dan komplikasi penyakit memiliki hubungan dengan kejadian MRS. Kemungkinan melalui cara inilah derajat penyakit dapat diterapkan sebagai penyebab MRS.

Pada penelitian kami, 31,4\% subyek penelitian memiliki diagnosis multipel dan $88 \%$ merupakan pasien dengan penyakit kronis, seperti keganasan, penyakit jantung bawaan, dan pneumonia berulang. Lama rawat yang dilatarbelakangi penyakit kronis dan diagnosis multipel merupakan faktor risiko MRS. ${ }^{1}$ Pasien malnutrisi pada saat masuk rumah sakit, 42,8\% merupakan pasien dengan diagnosis multipel. ${ }^{19}$ Namun, analisis multivariat keduanya tidak memiliki hubungan yang bermakna. Diagnosis multipel tidak memiliki hubungan dengan asupan makan, tetapi memiliki hubungan dengan komplikasi penyakit. Di samping itu, komplikasi penyakit memiliki hubungan dengan kejadian malnutrisi rumah sakit. Diagnosis multipel berdampak pada lama rawat yang menyebabkan peningkatan kejadian komplikasi penyakit. ${ }^{20}$
Demam bukan merupakan faktor predikor MRS pada anak, sedangkan pada penelitian lain dilaporkan demam selama 3 hari merupakan faktor risiko terjadinya malnutrisi rumah sakit pada anak. ${ }^{21}$ Oleh karena itu, pada kondisi ini terjadi hipermetabolisme dan deplesi nutrien. Peningkatan konsumsi energi dapat mencapai 11,3\%-13\% dalam setiap peningkatan $1{ }^{\circ} \mathrm{C}$, disertai peningkatan ekskresi nitrogen dalam urin. ${ }^{22,23}$ Scoring of pyrexia menyebutkan bahwa suhu di atas $37,5^{\circ} \mathrm{C}$ memiliki risiko mengalami sepsis terutama pada pasien dengan derajat penyakit yang lebih berat sehingga perlu dilakukan skoring. ${ }^{13}$

Asupan makan, status nutrisi, diare, dan keganasan bukan merupakan faktor prediktor dalam penelitian kami. Pada awal rawat, anak cenderung mengalami penurunan nafsu makan karena berada di lingkungan baru sehingga perlu adaptasi, di samping rasa dan teknik penyajian menu turut berpengaruh. Selain itu, proses penyakit yang sedang berjalan memengaruhi nafsu makan pasien apalagi bila melibatkan keluhan pada sistem gastrointerstinal. ${ }^{24}$ Beberapa kondisi lain yang memperberat keadaan di antaranya memuasakan pasien untuk tindakan diagnostik serta tidak adanya tenaga khusus di rumah sakit yang bertugas memberikan asupan makan bagi pasien yang memerlukan. ${ }^{25}$

Malnutrisi rumah sakit lebih banyak terjadi pada anak dengan status nutrisi awal gizi baik (66,7\%). Wasted bersifat protektif terhadap insiden MRS karena pasien memiliki massa tubuh minimal untuk katabolisme, apalagi perhatian klinisi pada umumnya lebih banyak pada pasien tersebut. ${ }^{2}$ Berbagai intervensi nutrisi yang telah dilakukan pada penderita gizi kurang dan gizi buruk kemungkinan telah memengaruhi hasil akhir.

Kejadian diare yang rendah pada 2 hari pertama rawat $(4,9 \%)$ kemungkinan turut memengaruhi hasil penelitian kami. Penelitian lain melaporkan bahwa diare yang berlangsung selama 3 hari merupakan faktor risiko MRS. ${ }^{21}$ Laporan lain menyebutkan diare tidak menyebabkan penurunan berat badan selama perawatan karena pasien pada kelompok ini telah mendapat intervensi nutrisi dari ahli gizi pada awal masuk rumah sakit. ${ }^{14}$

Faktor yang memengaruhi kejadian malnutrisi pada anak dengan keganasan ditandai dengan anoreksia, kehilangan nafsu makan, penurunan berat badan, atrofi muskular, disfungsi sistem imun dan perubahan metabolisme tubuh. ${ }^{26}$ Malnutrisi pada keganasan dapat terjadi akibat dari pertumbuhan tumor yang 
berpotensi mengganggu sistem cerna, respon tubuh terhadap perkembangan sel ganas dan efek terapi yang ditimbulkan. ${ }^{26,27}$ Hospitalisasi berulang dan lama pada kondisi ini turut meningkatkan risiko malnutrisi. Beberapa penelitian melaporkan bahwa keganasan merupakan faktor prediktor MRS. ${ }^{14,28}$ Manifestasi klinis yang sering muncul pada keganasan, seperti penurunan berat badan, asupan makan yang menurun, dan gangguan sistem gastrointerstinal sebagai faktor prediktor MRS., 29

Delapanpuluh dua persen pasien keganasan sedang menjalani kemoterapi dalam 1 bulan terakhir. Obat-obatan jenis kortikosteroid, seperti prednison, deksaametason, dan metilprednisolon yang menyebabkan retensi cairan, moon face, dan meningkatkan nafsu makan sering digunakan pada masa ini kemungkinan turut memengaruhi berat badan pasien. Penelitian lain melaporkan bahwa pasien acute lymphoblastic leukemia (ALL) pada awal diagnosis biasanya berada dalam kondisi malnutrisi, tetapi apabila sudah mendapat kemoterapi menjadi gizi baik akibat penggunaan obat seperti kortikosteroid. ${ }^{30}$ Kelemahan penelitian kami tidak memperhitungkan penggunaan steroid yang memengaruhi keluaran. Terdapat 9,8\% subyek penelitian loss to follow up yang akan memengaruhi validitas penelitian.

Disimpulkan bahwa derajat penyakit 3 merupakan faktor prediktor malnutrisi rumah sakit pada anak, yang diperantarai oleh komplikasi penyakit yang terjadi.

\section{Daftar pustaka}

1. Sidiartha I.G.N. Insidensi malnutrisi rawat inap pada anak balita di Rumah sakit Umum Pusat Sanglah Denpasar. Sari Pediatri 2008;9: 381-5.

2. Kac G, Camacho-Dias P, Silva-Coutinho D, Silveira-Lopes R, Vilas-Boas V and Pinheiro ABV. Length of stay is associated with incidence of in-hospital malnutrition in a group of low income Brazilian children. Salud Publica Mex 2000; 42:407-12.

3. Pirlich M, Schutz T, Kemps M, Luhman N, Minko N, Lubke HJ, Rossnagel K, Willich SN and Lochs H. Social risk factors for hospital malnutrition. Nutrition 2005;21:295-300.

4. Nasar SS, Susanto JC, Lestari ED, Djais J. dan Prawitasari T. Malnutrisi di rumah sakit. Dalam Buku Ajar Nutrisi Pediatrik dan Penyakit Metabolik. Jilid 1. Ikatan Dokter Anak Indonesia (IDAI). Jakarta: Badan Penerbit IDAI;2011.h.165-6
5. Gerasimidis K, Keane O, Macleod I, Flynn DM and Wright CM. A four-stage evaluation of the Paediatric Yorkhill Malnutrition Score in a tertiary paediatric hospital and a distric general hospital. Br J Nutr 2010;104:751-6.

6. Isabel M, Correia TD, Waitzberg D. The impact of malnutrition on morbidity, mortality, length of hospital stay and costs evaluated through a multivariate model analysis. Clin Nutr 2003;22:235-9

7. Deldago AF, Okay TS, Leone C, Nichols B, Negro GMD, Vaz FAC. Hospital malnutrition and inflamatory response in critically ill children and adolescents admitted to a tertiary intensive care unit. Clinics 2008;63:357-62.

8. Kelly IE, Tessier S, Cahill A, Morris S, Crumley A, McLaughlin $\mathrm{D}$, McKee RF, Lean MEJ. Still hungry in hospital: identifying malnutrition in acute hospital admissions. QJ Med 2000;93:93-8.

9. Nesa NNM, Sidiartha GL, Prawirohartono EP, Suandi KG. Accuracy of modified simple pediatric nutritional risk score to detect in hospital malnutrition. Paediatr Indones 2010; 50:305-9.

10. Puryatni A, Ramadan N, Yanuar. Incidence of hospital malnutrition at pediatric ward saiful anwar hospital. Dalam: Kumpulan Naskah Lengkap PIT IV IKA Medan. Medan: PIT IV IKA;2010.h.108-9.

11. Anzar J, Nazir M. Hospital malnutrition in department of child medical school university of sriwijaya/ Mohammad Hoesin Hospital Palembang. Dalam: Kumpulan Naskah Lengkap PIT IV IKA Medan. Medan: PIT IV IKA; 2010.h. 76-8.

12. Fatimah N. Malnutrisi di rumah sakit. Majalah Gizi Medik Indonesia 2002;1:1: 4-8.

13. Dionigi R, Cremaschi RE, Jemos V, Dominioni L, Monico R. Nutritional assesment and severity of illness classification systems: A critical review on their clinical relevance. Word J Surg 1986;10:2-11.

14. Sermet-Gaudelus I, Poison-Salomon A, Colomb V, Brusset M, Mosser F, Berrier F and Ricour, C. Simple pediatric nutritional risk score to identify chidren at risk of malnutrition. Am J Clin Nutr 2000;72: 64-70.

15. Winkler MF, Malone AM. Medical nutrition therapy for metabolic stress: sepsis, trauma burns and surgery. Food, Nutrition \& Diet Therapy. Edisi ke-11. Philadelphia: Saunders Elsevier; 2004.h.1058-80.

16. Shenkin A. Serum prealbumin: Is it a marker of nutritional status or of risk of malnutrition? Clin Chem 2006;52:12:2177-9.

17. Devote G, Gallo F, Marchello C, Racchi O, Garbarini R, Bonassi S, Albalustri G, Haupt E. Prealbumin serum concentrations as a useful tool in the assessment of malnutrition in hospitalized patients. Clin Chem 2006;52:12:2281-5. 
18. Beck FK, Rosenthal TC. Prealbumin: a marker for nutritional evaluation. Am Fam Physician 2002;65:1575-8.

19. Pawellek I, Dokoupil K and Koletzko B. Prevalence of malnutrition in Rivadeniera DE, Evoy D, Fahey TJ, Lieberman MD, Daly JM. Nutritional support on cancer. Ca J Clin 2008;48:69-80.

20. Merritt RJ. and Suskind RM. Nutritional survey of hospitalized pediatric patiens. Am J Clin Nutr 1979;32:1320-5.

21. Campanozzi A, Rutigliano I and Russo M. Risk factor outcome of hospital malnutrition in children. JPNG 2004; 39:S505-6.

22. Benhariz M, Goulet O, Salas J, Colomb V, Ricour C. Energy cost of fever in children on total parenteral nutrition. Clin Nutr 1997;16:251-5.

23. Du Bois EF. The basal metabolism in fever. JAMA 1921; 77:352-5.

24. Juffrie M, Soenarto SSY, Oswari H, Arief S, Rosalina I, Mulyani NS. 2010. Buku Ajar Gastroenterologi-Hepatologi. UKK Gastrohepatologi-Enterologi IDAI.Jakarta: Badan
Penerbit IDAI;2010.h.87-120.

25. Hendrikse KM, Duggan C, Walker. 2005. Nutritional assessment in sick hospitalized children. Manual Pediatric Nutrition. Third edition. Philadelphia: BC Decker Publisher; 2005.h.1173-85.

26. Rivadeniera DE, Evoy D, Fahey TJ, Lieberman MD, Daly JM. Nutritional support on cancer. Ca J Clin 1998;48:69-80.

27. Mahan K, Esscot-Stamp S. Food, nutrition \& diet therapy. Edisi ke-11. Philadelphia: Saunder Elsevier;2004.

28. Hulst JM, Zwart H, Hop WC, Joosten KFM. Dutch national survey to test the STRONGkids nutritional risk screening tool in hospitalized children. Clin Nutr 2010;29:106-11.

29. Secker DJ and Jeejeebhoy, K.N. Subjective global nutritional assessment for children. Am J Clin Nutr 2007;87:1083-9.

30. Halton JM, Atkinson SA, Barr RD. Growth and body composition in response to chemotheraphy in children with acute lymphoblastic leukemia. Int J Cancer Suppl 1998;11: 81-4. 